\title{
PLAN TOPOGRAFI BERKOMPUTER
}

\author{
Musa b. Mohd. Lazim* \\ Samsudin b. Ahmad** \\ Institut Sains Komputer \\ Universiti Teknologi Malaysia
}

\section{Sinopsis}

Makalah penyelidikan ini membincangkan kaedah pengumpulan data-data ukur dari tempat pengukuran dan digunakan untuk memelot terus melalui komputer. Dalam konteks ini, kerja-kerja manusia telah dapat dikurangkan lebih daripada $75 \%$.

\section{Pendahuluan}

Sistem maklumat topografi (atau rupabumi) yang paling sesuai ialah peta topografi. Dalam sistem ini, kedudukan relatif butiran-butiran yang terdapat di atas permukaan bumi, sama ada semulajadi atau buatan manusia, akan digambarkan dalam bentuk lukisan. Lukisan ini dibuat pada skala dan unjuran yang telah ditetapkan dengan menggunakan simbol-simbol khas. Simbol-simbol ini telah direka dengan sedemikian rupa supaya butiran-butiran yang ditunjukkan oleh peta berkenaan dapat dibezakan dengan jelas oleh pengguna.

\section{Kaedah Penghasilan}

Peta topografi dapat dihasilkan dengan tiga cara, iaitu cara konvensional, cara fotogrametrik dan cara penderiaan jauh (remote sensing).

\section{Pemetaan Cara Konvensional}

Dengan cara ini, pemetaan akan dimulakan dengan membuat pengukuran semua kawasan yang akan dipetakan. Semua butiranbutiran di atas permukaan bumi akan diukur dengan kaedah-kaedah tertentu supaya gambaran permukaan bumi berkenaan dapat dilukiskan. Lukisan (biasanya dipanggil plotan) akan dibuat oleh manusia berdasarkan analisis hasil kerja ukur berkenaan untuk menghasilkan peta topografi.

\section{Pemetaan Cara Fotogrametrik}

Cara fotogrametrik memerlukan pengambilan gambar daripada udara untuk kawasan yang akan dipetakan dengan menggunakan pesawat udara dan kamera khas. Dengan menggunakan perkakas khas, gambar berkenaan dapat dimodelkan kembali dan plotan dapat dibuat secara langsung. Walau bagaimanapun, pengukuran di lapangan masih diperlukan bagi mendapatkan titik-titik kawalan untuk tujuan plotan.

\section{Pemetaan Cara Penderiaan Jauh}

Cara penderiaan jauh ini merupakan satu teknologi pemetaan yang baru. Dengan cara ini, satelit-satelit khas dilancarkan ke angkasa supaya ia dapat mengambil gambar-gambar muka bumi (dalam bentuk digital) dan memancarkan data berkenaan ke stesen di bumi. Data-data yang diterima di bumi akan diproses menggunakan komputer supaya model muka bumi yang berkenaan dapat dibina dan dipaparkan semula. Dengan demikian pemetaan akan dapat dilakukan dengan mudah. Walau bagaimanapun kerja di lapangan masih diperlukan untuk mendapatkan titik-titik kawalan.

\section{Penggunaan Peta Topografi}

Peta topografi merupakan dokumen-dokumen yang sangat penting untuk kegunaan ketenteraan dan kegunaan awam. Daripada dokumen-dokumen ini, semua perancangan-perancangan khasnya untuk pembangunan kawasan seperti pembinaan jalan raya, empangan, perumahan dan perparitan akan dapat dibuat dengan sempurna. Sebarang kesilapan maklumat akan mengakibatkan perlaksanaan perancangan berkenaan terpaksa dikaji semula atau tergendala. Walau bagaimanapun, disebabkan batasan-batasan peta berkenaan, ia hanya digunakan pada perancangan peringkat awal sahaja. Di antara batasan-batasan peta berkenaan, ialah ketepatan peta. Ketepatan peta adalah rendah kerana skalanya yang kecil. Dengan skala yang kecil ini juga menyebabkan tidak banyak butiran-butiran yang dapat ditunjukkan dan perancangan terperinci tidak dapat dilakukan. 


\section{Plan topografi}

Plan topografi adalah serupa dengan peta topografi kecuali ciri-cirinya sahaja yang berbeza. Di antara ciri-ciri utama plan topografi adalah seperti berikut:-

a. Skala.

Skala plan adalah besar dibandingkan dengan peta dan hanya merangkumi satukawasan yang kecil sahaja. Dengan demikian, banyak maklumat-maklumat dapat ditunjukkan dengan jelas dan dengan ketepatan yang tinggi.

\section{b. Kegunaan}

Oleh kerana ketepatan dan maklumat yang ada padanya, plan ini dapat digunakan untuk perancangan terperinci, misalnya di dalam menentukan isipadu tanah dalam kerja-kerja kejuruteraan.

\section{c. Warna}

Warna tidak diutamakan dalam plan. Semua maklumat ditunjukkan dengan dakwat hitam. Ini adalah kerana kaedah penerbitannya yang tidak menggunakan mesin cetak dan penghasilan yang segera.

\section{d. Pengguna}

Pengguna plan adalah terhad. Hanya pengguna tertentu seperti pemaju perumahan atau jurutera yang terlibat dalam perancangan guna tanah sahaja yang menggunakan plan ini.

\section{Rekabentuk Plan}

Plan hanya dapat dihasilkan berdasarkan plotan titik-titik yang mewakili rupabumi kawasan berkenaan. Kedudukan planimetrik maklumat-maklumat diperolehi daripada koordinat $\mathrm{x}$ dan $\mathrm{y}$, manakala perbezaan ketinggian diperolehi daripada koordinat $\mathrm{z}$. Secara ringkas, sistem koordinat kartesian digunakan. Koordinat yang terlibat ialah:

1. Koordinat paksi $x$ (timur/barat).

2. Koordinat paksi y (utara/selatan)

3. Koordinat paksi z (ketinggian).

Kordinat-kordinat berkenaan hanya boleh diperolehi dengan menganalisa data-data kerja ukur yang telah dijalankan.

Tujuan utama rekabentuk plan ialah untuk menghasilkan plan yang dapat menggambarkan maklumat-maklumat dengan jelas pada skala yang tertentu. Di dalam mereka bentuk plan, perkara-perkara yang berikut perlu dipertimbangkan:
a. Sistem rujukan
b. Tanda-tanda lazim
c. Gaya penulisan
d. Penggambaran jasad timbul (relief)
e. Maklumat pada jidar

\section{Sistem Rujukan}

Sistem rujukan merupakan garisan kawalan yang mempunyai koordinatnya sendiri. Ia boleh digunakan untuk mendapatkan koordinat titik-titik lain pada plan. Garisan rujukan ini menjadi sangat penting jika plan berkenaan mengandungi dua atau lebih lembaran.

Sistem rujukan ini boleh berbentuk sama ada grid segiempat atau persilangan garisan seperti yang terdapat pada gambarajah 1 .

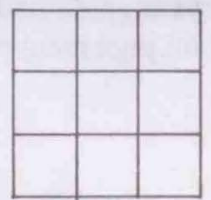

Grid Segiempat

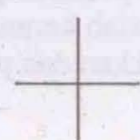

Persilangan Garisan

Gambarajah 1 Sistem Rujukan 
Persilangan garisan ini boleh dijadikan panduan untuk menyatukan plan jika terdapat dua atau lebih lembaran. Setiap persilangan garisan mempunyai koordinat (dua dimensi) yang tetap. Koordinat titik lain boleh didapati dengan merujuk kepada persilangan yang terhampir.

\section{Tanda-tanda Lazim}

Tanda lazim merupakan bentuk ringkas maklumat-maklumat yang hendak digambarkan. Ciri-ciri tanda lazim berkenaan mestilah:

a. Jelas, kemas dan mudah dihasilkan.

b. Beberapa titik atau tanda menunjukkan kedudukan sebenar maklumat.

c. Menunjukkan kepentingan maklumat secara relatif.

Tanda lazim ini sangat mustahak di dalam pembuatan plan atau peta. Bentuk maklumat yang serupa dengan keadaan yang sebenar tidak dapat ditunjukkan pada plan kerana:

a. Bentuk sebenar sukar untuk dibentuk.

b. Plan menjadi padat dengan maklumat dan menjadi tidak kemas.

c. Tidak banyak maklumat yang berlainan dapat ditunjukkan.

Oleh yang demikian, maklumat-maklumat seperti jalan, sempadan, kawasan berair dan bangunan akan digambarkan dengan menggunakan simbol-simbol yang khas. Biasanya simbol-simbol ini adalah serupa untuk kebanyakan plan atau peta supaya plan berkenaan mudah difahami. Bagi kemudahan pengguna, simbol ini juga disenaraikan dengan jenis atau nama maklumat pada bahagian tertentu plan.

\section{Gaya Penulisan}

Semua penulisan perlulah jelas dan mudah dibaca. Penulisan ini hanya sebagai tambahan untuk menjelaskan maklumatmaklumat yang telah digambarkan. Penulisan yang banyak atau gaya yang keterlaluan akan menyebabkan plan sukar dibaca. Misalnya nama tempat, nama jalan dan ketinggian titik tertinggi atau terendah.

\section{Penggambaran Jasad Timbul}

Kaedah untuk menggambarkan keadaan sebenar rupabumi di atas kertas secara lukisan dipanggil penggambaran jasad timbul. Terdapat beberapa kaedah yang boleh digunakan untuk menggambarkan jasad timbul. Kaedah yang kerap digunakan ialah:-

a. Kontor

Kontor adalah garisan-garisan yang menghubungkan titik-titik yang mempunyai ketinggian yang sama. Ciri-ciri rupabumi kawasan berkenaan dapat diketahui dengan menganalisa garisan kontor ini. Sela kontor dipilih berdasarkan kepada skala dan bentuk rupabumi kawasan berkenaan.

b. Ketinggian titik

Ketinggian titik merupakan kaedah yang sangat berkesan untuk membantu kontor. Dengan cara ini, titik-titik berkenaan ditandakan dan diberikan nilai ketinggiannya.

\section{Maklumat Pada Jidar}

Semua maklumat selain daripada maklumat yang perlu ditunjukkan pada plan mestilah disatukan dan diletak pada jidar. Biasanya ia diletak pada bahagian bawah atau kanan plan. Maklumat ini $t$ ermasuklah maklumat mengenai skala, tarikh pengukuran, kedudukan kawasan dan tuan punya tanah berkenaan.

\section{Sistem Masa Kini}

Pada masa ini, penggunaan komputer untuk tujuan penghasilan plan topografi masih belum begitu meluas. Penggunaannya biasanya terhad dalam aspek pengiraan sahaja. Di dalam aspek lain, penggunaannya adalah tidak menggalakkan disebabkan oleh kos yang agak tinggi dan kurangnya pendedahan ke arah penggunaan komputer sepenuhnya.

Plan akan hanya dihasilkan jika terdapat permintaan. Penghasilan plan dilakukan dengan kaedah konvensional dan oleh manusia. Secara ringkas, penghasilan plan dapat adalah seperti yang ditunjukkan dalam gambarajah 2 . 


\section{Permasalahan}

Terdapat beberapa masalah yang telah dikenalpasti jika sistem masa kini diteruskan. Di antara masalah berkenaan ialah:

\section{Tenaga mahir}

Kerja-kerja ukur dan plotannya memerlukan tenaga kerja yang mahir supaya plan yang baik dapat dihasilkan. Tanpa tenaga mahir ini, masa yang panjang diperlukan untuk menghasilkan plan yang baik.

\section{Masa}

Masa yang panjang diperlukan untuk membuat kerja di lapangan dan semasa membuat plotan. Semua kerja yang telah dibuat perlu disemak dengan teliti dan ia dilakukan oleh manusia. Semakan begini akan memakan masa yang panjang di samping menjemukan kerana rutin yang sama untuk semua kerja yang telah dijalankan.

\section{Skala}

Skala plan adalah telah ditetapkan oleh pembuat plan atau oleh pemohon. Sebarang pertukaran skala akan memerlukan penghasilan semula dan akan memakan mas yang agak panjang. Dengan kata lain, skala plan adalah tetap.

\section{Ubahsuai}

Plan tidak boleh diubahsuai dengan sewenang-wenangnya kerana ia akan menjejaskan kualiti dan maklumat-maklumat lain dalam plan berkenaan. Ubahsuai ini juga memakan masa yang agak panjang.

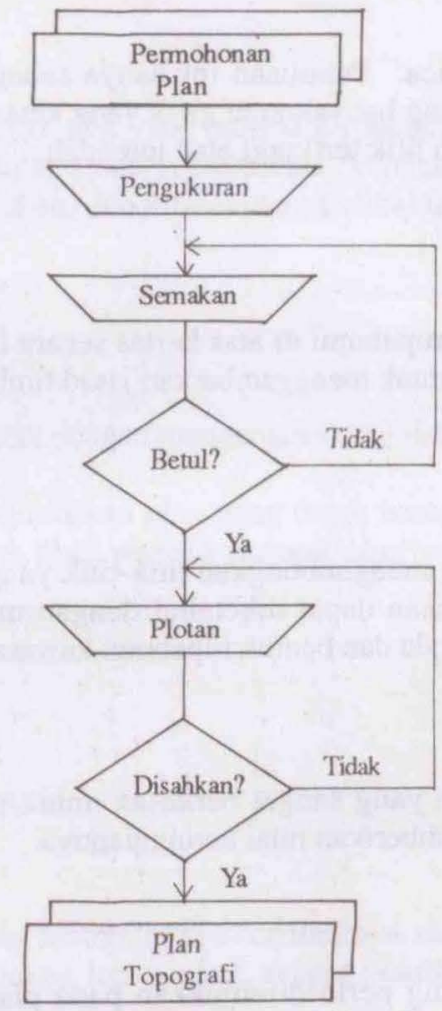

Gambarajah 2 Penghasilan Plan Topografi

\section{Plan Topografi Berkomputer}

Penghasilan plan, daripada pengukuran di lappangan sehingga menghasilkan plan kawasan berkenaan memerlukan masa yang panjang di samping tugas yang mencabar. Ramai tenaga pekerja diperlukan dengan kemahiran tertentu supaya plan yang bermutu dan boleh dipercayai dapat dihasilkan.

Sistem plan topografi berkomputer merupakan satu sistem yang boleh mengendalikan penghasilan plan berkenaan daripada peringkat awal hingga akhir. Sistem ini membolehkan pengguna berinteraksi dengan komputer secara langsung untuk menghasilkan plan seperti mana yang dikehendaki. 


\section{Tatasusunan Sistem}

Pada amnya, sistem plan topografi berkomputer ini adalah sama dengan sistem yang ada, kecuali penggunaan komputer sahaja. Tatasusunan plan topografi berkomputer yang dicadangkan adalah seperti yang terdapat pada gambarajah 3.

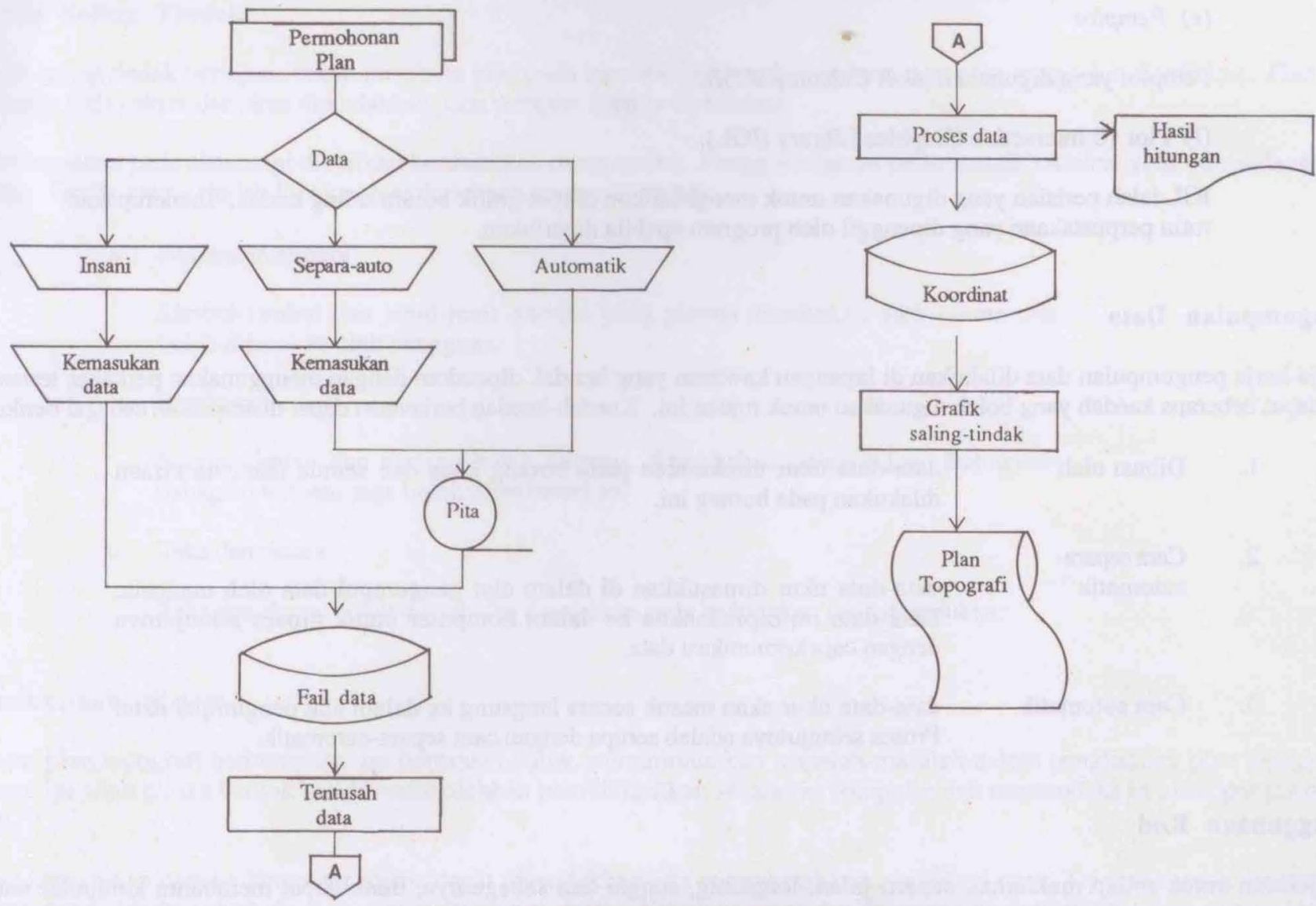

Gambarajah 3 Plan Topografi Berkomputer

Sistem plan topografi ini melibatkan tiga fasa utama. Setiap fasa mempunyai fungsi dan tugas yang berbeza. Fasa yang berkenaan ialah fasa pengumpulan data, pemprosesan data dan grafik saling tindak.

\section{Perkakasan dan Keperluan}

Sistem ini dapat dijalankan dengan menggunakan perkakas dan keperluan yang berikut:

\section{(a) Komputer Bimbit EPSON HX-20}

Perkakas ini digunakan sebagai alat pengumpul data. Data-data dimasukkan dan disimpan pada pita magnetik yang ada pada komputer berkenaan. Komputer bimbit ini telah disediakan dengan liang RS232-C (menggunakan 8-pin DIN) untuk tujuan komunikasi tak segerak.

\section{(b) Komputer Peribadi IBM-XT $<$ RS-232-C dan IRMA}

Komputer ini akan menerima data daripada komputer bimbit EPSON HX-20 melalui liang RS-232-C (menggunakan 25 pin). Bagi tujuan komunikasi, hanya 9 daripada 25 pin sahaja yang akan digunakan. Data-data yang diterima akan disimpan dalam disket. Data-data dalam disket ini pula akan dipindahkan ke komputer grafik dengan menggunakan kad IRMA.

\section{(c) Kabel Penghubung}

Kabel penghubung ini diperlukan untuk menghubungkan komputer bimbit (8-pin DIN) dengan komputer peribadi ( $25 \mathrm{pin})$. 


\section{(d) Komputer Grafik}

Komputer grafik yang digunakan adalah Tektronik 4027 yang dihubungkan dengan kerangka utama sebagai pemprosesnya. Data-data pada komputer ini disimpan dalam cakera.

\section{(e) Pemplot}

Pemplot yang digunakan ialah Calcomp 905A.

(f) Plot 10 Interactive Graphies Library (IGL).

IGL ialah perisian yang digunakan untuk menghasilkan output grafik secara saling tindak. Ia merupakan rutin perpustakaan yang dipanggil oleh program apabila diperlukan.

\section{Pengumpulan Data}

Kerja-kerja pengumpulan data dilakukan di lapangan kawasan yang hendak dipetakan dengan menggunakan perkakas tertentu. Terdapat beberapa kaedah yang boleh digunakan untuk tujuan ini. Kaedah-kaedah berkenaan dapat disimpulkan sebagai berikut:

1. Dibuat oleh data-data ukur direkodkan pada borang khas dan semua manusia kiraan dilakukan pada borang ini.

2. Cara separaautomatik

data-data ukur dimasukkan di dalam alat pengumpul data oleh manusia. Data-data ini dipindahkan ke dalam komputer untuk proses selanjutnya dengan cara komunikasi data.

3. Cara automatik data-data ukur akan masuk secara langsung ke dalam alat pengumpul data. Proses selanjutnya adalah serupa dengan cara separa-automatik.

\section{Penggunaan Kod}

Penjelasan untuk setiap maklumat, seperti jalan, longkang, sungai dan sebagainya, tidak dapat membantu komputer untuk melaksanakan tugasnya. Dengan demikian kod-kod yang berbentuk angka digunakan. Setiap maklumat akan disenaraikan dan diberikan kod-kod yang tersendiri. Kod-kod ini direka bentuk supaya ia mudah digunakan.

\section{Komunikasi Data}

Komunikasi data bertujuan untuk memindahkan data-data yang telah disimpan oleh alat pengumpul data ke komputer. Datadata ini akan dipindahkan dengan cara komunikasi tak segerak menggunakan antara muka RS-232-C, di mana data-data ini akan dipindahkan secara bersiri. Antara muka RS-232-C ini dipilih berdasarkan kepada faktor:-

a. Kos yang rendah

Kos untuk mendapatkan antara muka ini adalah rendah dibandingkan dengan yang lain.

b. Piawaian

Pendawaian dan susunan pin untuk antara muka ini telah dipiawaikan.

c. Jam

Dengan kaedah ini, jam tidak diperlukan. Ini akan membolehkan komunikasi data dilakukan untuk peranti yang berlainan.

\section{Pemprosesan Data}

Tujuan utama pemprosesan data ialah untuk mendapatkan koordinat-koordinat setiap titik yang telah diukur. Proses ini dilakukan pada komputer grafik (komputer kerangka utama) berdasarkan kepada kod-kod jenis kerja.

Pemprosesan data merangkumi proses semakan dan hitungan. Semakan data akan melibatkan tentu sah penggunaan kod-kod dan data-data berangka. Hitungan yang biasa dilakukan dalam proses hitungan akan juga dapat dilaksanakan dalam fasa ini. 
Hasil yang diperolehi daripada fasa ini ialah senarai ralat data (jika ada) dan senarai koordinat xyz setiap titik. Senarai koordinat ini akan digunakan untuk proses yang selanjutnya. Data-data ini dibahagikan berdasarkan kepada jenis supaya sistem ini dapat beroperasi dengan berkesan.

\section{Grafik Saling Tindak}

Grafik saling tindak bertujuan untuk membina plan pada terminal berdasarkan senarai data-data yang telah disediakan. Plan ini disimpan pada cakera dan akan dipindahkan pada pemplot apabila diperlukan.

Arahan-arahan pada sistem ini diberikan berdasarkan menu-menu. Pengguna hanya perlu memilih arahan yang ada pada menu sahaja. Grafik saling tindak ini akan membolehkan pengguna untuk:

a. Penjanaan simbol

Simbol-simbol dan jenid-jenis garisan yang piawai disediakan oleh sistem dan boleh dijanakan oleh pengguna.

b. Suntingan

Semua simbol dan garisan boleh dihapus, ditambah dandianjakkan. Bahagianbahagian tertentu juga boleh diperbesarkan.

c. Teks dan aksara

Teks dan aksara boleh diletak dan diputarkan pada kedudukan yang diperlukan.

\section{Kemampuan Sistem}

Sistem plan topografi berkomputer ini bertujuan untuk meminimumkan masalah-masalah dalam penghasilan plan topografi. Sistem ini telah direka bentuk untuk membolehkan plan dihasilkan secara berkomputer dan memendekkan masa penghasilan plan.

Masa kemasukan data ke komputer utama dapat dipendekkan jika menggunakan komunikasi data. Dengan cara ini komputer utama akan dihubungkan dengan alat pengumpul data. Kesalahan semasa kemasukan data akan dapat dihapus atau diminimumkan jika menggunakan cara ini.

Kemasukan data, pemprosesan dan output dapat dilakukan oleh komputer dengan bantuan operator. Sistem ini mampu untuk melaksanakan pemprosesan semua jenis kerja yang biasa dilakukan oleh manusia dengan data-data yang banyak bilangannya. Dengan kata lain, tiada batasan bilangan data untuk tujuan pemprosesan. Walau bagaimanapun, jenis kerja yang terlibat adalah terbatas untuk:
a. Ukur aras
b. Ukur tekimetri
c. Ukur rentasan
d. Ukur ketinggian trigonometrik
e. Cerapan matahari untuk azimut

Batasan-batasan sistem ini hanya akan ketara pada fasa grafik saling tindak. Batasan-batasan berkenaan ialah:

a. Keratan rentas

Sistem ini tidak dapat menyediakan bentuk keratan rentas untuk satu-satu kawasan tertentu kerana imej yang dihasilkan adalah dalam bentuk dua dimensi.

b. Perbezaan skala

Perbezaan skala yang besar antara plan-plan tidak dapat dilakukan kerana ia melibatkan pembesaran atau penghapusan maklumat-maklumat tertentu. 


\section{Rujukan}

1. Bos, E.S.: Cartographic principles in thematics mapping. ITC Cartographics Department, Enschede, 1973.

2. Epson Corporation: Portable computer HX-20: Basic reference manual, Nagano, Japan, 1982.

3. Harrington, S: Computer Graphics: A programming Approach.International Student Edition, S'pore: McGraw-Hill Book Company, 1986.

4. Tektronix Inc.: Plot 10 4010C01 Interactive Graphics Library: Option 4A-Segments, Part No. 070-44850-00, Product Group 11, Beaverton, USA, 1982. 